\title{
Assessment of Selected Hepatic Serum Enzymes in Contaminated Crude-Oil Feeds on Albino Wistar Rats
}

\author{
R.U. Ukpanukpong ${ }^{1}$, D.I. Basiru ${ }^{1}$, O.O. Obadare ${ }^{2}$ and W.A. Omang ${ }^{1}$ \\ ${ }^{1}$ Department of Biochemistry, Faculty of Basic Medical Sciences, \\ University of Calabar, Nigeria \\ ${ }^{2}$ Department of Biochemistry, College of Natural Sciences, Joseph Ayo Babalola University, \\ Ikeji-Arakeji Osun State, Nigeria \\ *Corresponding author
}

A B S T R A C T

This study was aimed at investigating the effect of crude oil contaminated feeds on selected serum enzymes and electrolyte levels in Albino wistar rats. Albino wistar rats weighing between $180 \mathrm{~g}$ to $200 \mathrm{~g}$ were obtained from Ladoke Akintola University of

Keywords

Body weight, Serum enzymes, Electrolyte level

Article Info

Accepted:

04 July 2018

Available Online:

10 August 2018

Technology Ogbomosho, OyoState and used for the study. The animals were grouped into five study groups with six (6) animals in each group. The animals were kept in a wellventilated room comprising control group, crude oil group, garlic treated group, Vitamin C treated group and Vitamin E treated group. The animals were fed with contaminated feeds $25 \mathrm{mg}$ of the antioxidant specified for each group simultaneously for two weeks. However, control group were only fed with the normal while the crude oil group was not treated with the antioxidant. The levels of LDH and GGT concentrations increased significantly ( $\mathrm{P}>0.05)$ in crude oil only fed group but LDH showed low concentration on treatment with vitamin $\mathrm{E}(\mathrm{P}<0.05)$. Garlic and vitamin $\mathrm{C}$ therefore do not have ameliorative effect on increased LDH and GGT levels of crude oil contamination. Vitamin $\mathrm{E}$ therefore reduced the toxic effect of the crude oil contamination on LDH significantly after 28 days. There was a significant increased $(\mathrm{P}>0.05)$ in the activities of AST, ALT, ALP in groups fed with crude oil contaminated diet when compared to the control and these sharp changes were ameliorated after 28 days of antioxidant treated groups.

\section{Introduction}

Nigeria is the sixth largest exporter of crude oil in the world as a result, its air, land and water are heavily polluted with crude oil and its refined products (Ita and Udofia, 2011). Crude oil and gas production is the main stay of the Nigeria economy contributing about $90 \%$ of the nation's foreign exchange, $80 \%$ of total government revenue earning and $25 \%$ of the gross domestic product (GDP) (Niger Delta Development Commission, 2006). Crude oil and gas pollution is the major environmental hazard caused by crude oil and gas exploration, exploitation and production in the Niger Delta region of Nigeria and many parts of the world (Wang et al., 2010). Crude oil and gas pollution can occur in form of 
spillages due to oil well blowout, corrosion of pipelines, accidental discharges and vandalization. These oil spillages can lead to underground leakages which have impacts on the environment in the form of underground water pollution, soil pollution, health effect and destruction of vegetation (Alam et al., 2010).

In Nigeria today, contamination as a result of oil spillage has become one of the severest forms of environmental pollution. Generally, petroleum and its refined products reaching the terrestrial and aquatic ecosystems arrive as a consequence of spillage which may result from natural seepages, offshore exploration, leakages from wells or from oil tankers, accident from oil tankers, land based discharges and sabotage. The toxic effect of crude oil hydrocarbons in an organism is manifested afterwards to bioaccumulation of the offending xenobiotics.

Currently, widespread concern exists regarding the presence of pollutants in the environment which can interfere with normal endocrine functions in animals, including humans. Particular attention has been focused on chemicals that are capable of mimicking or modulating the effects of gonadal hormones, thereby potentially interfering with the reproductive processes and behaviors of organisms (Doyle and Lim, 2002).

Traditional toxicological testing has focused on the ability of substances to cause obvious harm to adult or developing animals at high doses. Some endocrine disruptors are able to affect the hormonal system at very low doses, causing subtle disorders that may not be readily apparent or that may be delayed, even onto the next generation. The discovery that chemicals could cause harm to animals and possibly to humans also in such subtle ways at low doses has challenged traditional views of toxicity and expanded gaps in toxicity testing in organism (Doyle and Lim, 2002). The impact of crude oil spillage and discharge on the ecosystem as a result of oil exploration activities is an obvious problem of environmental concern. Similarly, the use of crude petroleum as therapeutic and in folkloric medicine in some parts of mineral oil producing communities in the Niger-Delta is another deliberate exposure with obvious health implications. Again, the exposure of workers in the oil industries may bring about a harvest of ill health, diseases and even death.

There are accumulating evidences which indicate that humans, domestic and wildlife species are suffering from adverse health consequences from exposure to environmental chemicals that interact with the endocrine system. According to Patrick-Iwuanyanwu et al., (2011), petroleum has the potential to elicit multiple types of toxic effects due to its complicated composition. In experimental animals, petroleum products have been demonstrated to have adverse effects including the generation of free radicals (Achuba and Osakwe, 2003), increase in serum levels of urea and creatinine and significant degenerative changes in the structural integrity of hepatic and renal cells (Patrick-Iwuanyanwu et al., 2011). Acute toxicity study of diesel fuel in rats (Rattus rattus) indicated a dose-dependent hepatocellular necrosis and adverse alteration in structure and function of renal tubules.

Acute, chronic and long term effects of chemical compounds (including crude oil) on living systems could be studied by evaluating the biochemical and morphological changes in various organs especially the liver. The basic structural component of the liver is the liver cells or hepatocytes. The liver is the principal organ of metabolism and has a role to play in many body processes most especially detoxification of chemical compounds. Research studies have shown a variety of 
adverse effects on the hepatocytes of rats and catfish following exposure to environmentally toxic compounds (Sunmonu and Oloyede, 2006). In the present study, an attempt is made to carry out biochemical assessment of serum enzyme and electrolyte in ingested crude oil contaminated diets on Wistar Albino Rats.

Petroleum ("rock oil") is a naturally occurring, flammable liquid found in rock formations in the Earth consisting of a complex mixture of hydrocarbons of various molecular weights, plus other organic compounds. The proportion of hydrocarbons in the mixture is highly variable and ranges from as much as $97 \%$ by weight in the lighter oils to as little as $50 \%$ in the heavier oils and bitumens. The hydrocarbons in crude oil are mostly alkanes, cycloalkanes and various aromatic hydrocarbons while the other organic compounds contain nitrogen, oxygen and sulfur, and trace amounts of metals such as iron, nickel, copper and vanadium.

The exact molecular composition varies widely from formation to formation but the proportion of chemical elements varies over fairly narrow limits as follows. The typical nature of crude oil from different sources is different or less identical. The same is true for crude oil also; the individual oil even from the same well at different time of extraction is differing in the characteristics in term of chemical composition. Crude oils are complex but mainly paraffinic, napthenic and aromatic (Wang et al., 1994). Crude oils contain all normal alkenes from $\mathrm{C} 1$ to $\mathrm{C} 120$. However, this percentage rises to $35 \%$ in highly paraffmic and decreases to zero in highly biograded oils (Al-Turki, 2010). Methane is predominant component of natural gas and alkanes ranging from pentane to pentadecane are the chief constituents of straight run (uncrackcd) gasoline or petrol. Above C17, the alkanes are solid wax like substances and crude oils, which contain high concentrations of paraffin wax, will be viscous and have high cloud and pour points. These paraffins consist of isoalkanes and methyl cycloalkanes. Most commonly found naphthenes are five and six member rings and occasionally a few rings with seven carbon atoms. Among these, methyl derivatives are the most abundant compounds as compared with the parent bicycle compounds.

Crude oils contains up to $50 \%$ of such Oil pollution occurs when oil is introduced into the environment directly or indirectly by men's impacts resulting in unfavorable change in such a way that safety and welfare of any living organisms is endangered. Crude oil if spilled into the water spreads over a wide area forming a slick and oil in water immediately begins to undergo a variety of physical, chemical and biological changes including evaporation of high volatile fractions, dissolution of water-soluble fractions, photochemical oxidation, drill, emulsification, microbial degradation and sedimentation (Colbborn et al., 1993). Crude oil is a complex mixture of hydrocarbon and organic compounds of Sulphur, Nitrogen, Oxygen and a certain quantity of water which varies in composition from place to place (Ita and Udofia, 2011).

Crude oil is produced from decay of plants and animals over millions of years. It is also referred to as mineral oil. Crude oil, which is a mixture of hydrocarbons and inorganic compounds, is drilled through rocks.

Crude oil discharged on the sea surface undergoes physical, chemical and biological alteration. Rapid physical and chemical processes include spreading and movement by wind and currents, injection into the air, evaporation of volatile components, dispersion of small droplets into water, dissolution and chemical oxidation. Concurrent with these are relevant biological processes. They include 
degradation by micro-organisms and uptake by larger organisms followed by metabolism and storage or discharge (Nelson-Smith, 1972).

\section{Materials and Methods}

\section{Source of animals}

Wistar albino rats, aged between 6 and 8 weeks used for this research weighing between $180 \mathrm{~g}$ and $200 \mathrm{~g}$ were obtained from Ladoke Akintola University of Technology Ogbomosho Oyo State.

The animals were kept in the experimental cage in order to acclimatize to laboratory conditions. Regular and adequate feeding regimes for one week, i.e. 7 days, before the commencement of the experiment. They were fed on commercial growers' mash and water.

\section{Crude-oil}

The crude oil was obtained from the Shell terminal, well 4 of Shell oil. A class A oil, light and volatile Warri Delta State, Nigeria.

\section{Chemicals/Reagents}

All the chemicals used in this research were obtained from Famlab Nigeria Limited Lagos which is of reagent grade obtained from Merck, Germany; BDH chemicals Ltd, England; May and Baker Ltd, England; Riedel-De-Haen Hannover, Germany and Hopkins and Williams Essex, England.

\section{Formulation of contaminated diet}

$10 \%$ crude oil contaminated diet was obtained by thoroughly mixing $45 \mathrm{~g}$ of feed with $5 \mathrm{ml}$ of crude oil. The feed for the control group contained no crude oil (i.e. $0 \%$ group).

\section{Drug administration}

Three drugs: garlic, vitamin $\mathrm{C}$ and vitamin $\mathrm{E}$ were used for the study. The drugs were given orally using $2.5 \mathrm{mg} / \mathrm{kg}$ syringe.

\section{Experimental design}

The animals were grouped into five groups with each group having six animals including control. The animals were kept in a wellventilated room comprising control group, crude oil group, garlic treated group, Vitamin $\mathrm{C}$ treated group and Vitamin E treated group. The animals were fed with contaminated feed with $2.7 \mathrm{mg} / \mathrm{kg}$ of the drug specified for each group simultaneously for 28 days. However, control group were only fed with normal meal while the crude oil group was not treated with the antioxidant.

\section{Blood and serum collection}

At the end of the experimental period, the animals were given chloroform anaesthesia by inhalation to enable unclotted blood to be collected by cardiac puncture, (Thompson, 1983). With the aid of a $5 \mathrm{ml}$ syringe and needle, blood were being collected and suspended into EDTA plastic bottles. These were centrifuged at $1200 \mathrm{rpm}$ for 10 minutes to obtain serum for determination of enzymes and electrolyte levels.

\section{Determination of total serum bilirubin level}

\section{Method}

Colorimetric method by Jendrassik and Grof (1938).

\section{Principle}

Direct (conjugated) bilirubin reacts with diazotized sulphanilic acid in alkaline medium to form a blue coloured complex. Total 
bilirubin was determined in the enzyme presence.

\section{Determination of serum Aspartate Aminotransferase (AST) level}

\section{Method}

Colorimetric method.

\section{Principle}

$\alpha$-oxoglutarate + L-aspartate $\stackrel{\text { GOT }}{\longrightarrow}$ Lglutamate + oxaloacetate.

AST is measured by monitoring

The concentration of oxaloacetate hydrazine formed with 2,4-dinitrophenylhydrazine.

Determination of serum Alanine Aminotransferase (ALT) level

\section{Method}

Colorimetric method.

\section{Principle}

$\alpha$ - oxoglutarate $+\mathrm{L}$ - alanine $\stackrel{\mathrm{GPT}}{\longrightarrow} \mathrm{L}$ glutamate + pyruvate.

Alanine aminotransferase was measured by Monitoring.

The concentration of pyruvate hydrazine formed with 2, 4- dinitrophenylhydrazine.

$\begin{aligned} & \text { Determination of serum Alkaline } \\ & \text { Phosphatase }\end{aligned}$

\section{Method}

Colorimetric method.

Principle

$$
\mathrm{P}-\text { nitrophenylphosphate }+\mathrm{H}_{2} \mathrm{O} \underset{\text { phosphate }+\mathrm{P} \text {-nitrophenol }}{\stackrel{\text { ALP }}{\longrightarrow}}
$$

Determination of serum Gamma Glutamyl Tranferase ( $\gamma$-GT) Activity

\section{Method}

Colorimetric - Kinetic

\section{Principle}

At $\mathrm{pH} 7.8 \gamma$-GT in sample was made to catalyse the transfer of glutamyl terminal residue from $\gamma$-glutamyl-p-nitroanalide to the acceptor, glycyglycine to give yellow coloured $\gamma$ - glutamyl-glycyglycine. The rate of formation of the product monitored at $405 \mathrm{~nm}$ was proportional to the enzyme activity.

Determination of serum Electrolytes; $\mathrm{Na}^{+}$, $\mathrm{K}^{+}, \mathrm{Cl}$

\section{Method}

Ion Selective Electrodes (ISE)

\section{Principle}

A transducer (or sensor) converts the activity of a specific ion dissolved in a solution into an electrical potential which was measured by a voltmeter. The voltage was theoretically dependent on the logarithm of the ionic activity. The sensing part of the electrode was usually the ion-specific membrane, alone with a reference electrode (Eric et al., 2006).

\section{Statistical analysis}

All the results were expressed as means \pm SD and all data were analyzed using Analysis of variance (ANOVA).

Significant differences between the control and treatment groups were determined at $(\mathrm{P}<0.05)$ confidence level using Duncan's Multiple Range Test (Duncan,1995). 


\section{Results and Discussion}

Results of Lactate dehydrogenase (LDH), Serum Aspartate Transaminase (AST), Alkaline Phosphatase (ALP), Serum Alanine Transaminase (ALT) and Gamma Glutamate Transferase (GGT) were presented in figure 1 and 2 respectively. While results on Sodium electrolyte $\left(\mathrm{Na}^{+}\right)$, Potassium ion $(\mathrm{K}+)$, Chloride ion (Cl-) and bilirubin were presented in figure 3 and 4 respectively. The results showed that garlic, vitamin $\mathrm{C}$ and vitamin $\mathrm{E}$ drugs increased the concentration of Lactate dehydrogenase (LDH)and Gamma Glutamyl Transferase (GGT), significantly $(\mathrm{P}<0.05)$ when compared with the control group (Figure 1 and 2). Likewise there were significantly increased $(\mathrm{P}<0.05)$ in $\mathrm{LDH}$ concentration and GGT when compared with crude oil control. However, in vitamin E drug treatment LDH showed significant decrease $110.9 \pm 0.04(\mathrm{P}>0.05)$ in enzyme activity. The decrease in Alkaline Phosphatase (ALP) was significant $(\mathrm{P}>0.05)$ when compared with control 1 and control 2 (crude oil control) in figure 1 and 2. However, the ALP concentration increased in vitamin $\mathrm{C}$ treated sample 177.9 $\pm 0.05(\mathrm{P}<0.05)$. Generally, there was significant increase in concentration of ALT and AST level $(\mathrm{P}>0.05)$ compared with control 1 and control 2 (crude oil control) respectively. However, ALT in vitamin C treated showed significant decrease $94.9 \pm 0.04$ $(\mathrm{P}<0.05)$. Likewise in AST, there was significant decrease in garlic treated sample $89.0 \pm 0.06 \quad(\mathrm{P}<0.05)$. Significant differences $(\mathrm{P}<0.05)$ was observed due to treatment effects of vitamin $\mathrm{E}$ when compared with crude oil contaminated control 48.9 \pm 0.06 (Figure 1 and 2).

From figure 3 and 4, the levels of Sodium, Potassium, Chloride and Bilirubin were significantly low $(\mathrm{P}<0.05)$ when compared with control 1 while there were variations in the concentration of the electrolyte and bilirubin when compared with control 2 (crude oil control); $\mathrm{Na}^{+}$showed significantly increased $(\mathrm{P}>0.05)$ in vitamin $\mathrm{C}$ and Vitamin E treated groups $(152.0 \pm 0.02$ and $151.0 \pm 0.02)$ while it was significantly decrease $(\mathrm{P}<0.05)$ in garlic treated drug (143.0 \pm 0.02$)$. Potassium $(\mathrm{K}+) \quad$ decreased significantly $\quad(\mathrm{P}<0.05)$ $(13.6 \pm 0.02,33.6 \pm 0.03$ and $22.1 \pm 0.02)$ in garlic, vitamin $\mathrm{C}$ and vitamin $\mathrm{E}$ treated groups.

Table.1 Physicochemical analysis of crude oil

\begin{tabular}{|l|l|l|}
\hline S/N & PARAMETER & SAMPLE RESULTS \\
\hline 1. & $\mathrm{pH}$ & 9.250 \\
\hline 2. & Temperature $\left({ }^{\mathrm{c}} \mathrm{c}\right)$ & 29.900 \\
\hline 3. & Dissolved Oxygen $(\mathrm{Mg} / \mathrm{L})$ & 1241.460 \\
\hline 4. & Cod $(\mathrm{Mg} / \mathrm{L})$ & 169200.000 \\
\hline 5. & E.CONDUCTIVITY $(\mu \mathrm{scm})$ & 1950.000 \\
\hline 6. & Turbidity $(\mathrm{Ntu})$ & 220.000 \\
\hline 7. & Total Solids $(\mathrm{Mg} / \mathrm{L})$ & 1104.000 \\
\hline 8. & T. Dissolved Solids $(\mathrm{Mg} / \mathrm{L})$ & 975.000 \\
\hline 9. & T. Suspended Solids $(\mathrm{Mg} / \mathrm{L})$ & 129.000 \\
\hline 10. & Chlorides $(\mathrm{Mg} / \mathrm{L})$ & 4373.110 \\
\hline 11. & Phosphates $(\mathrm{Mg} / \mathrm{L})$ & 2051.980 \\
\hline 12. & Sulphates $(\mathrm{Mg} / \mathrm{L})$ & 65667.000 \\
\hline 13. & Bicarbonates $(\mathrm{Mg} / \mathrm{L})$ & 7200.000 \\
\hline
\end{tabular}


Figure.1 Effect crude oil contaminated feeds on serum enzymes level after 14 days of administration in Wistar rats

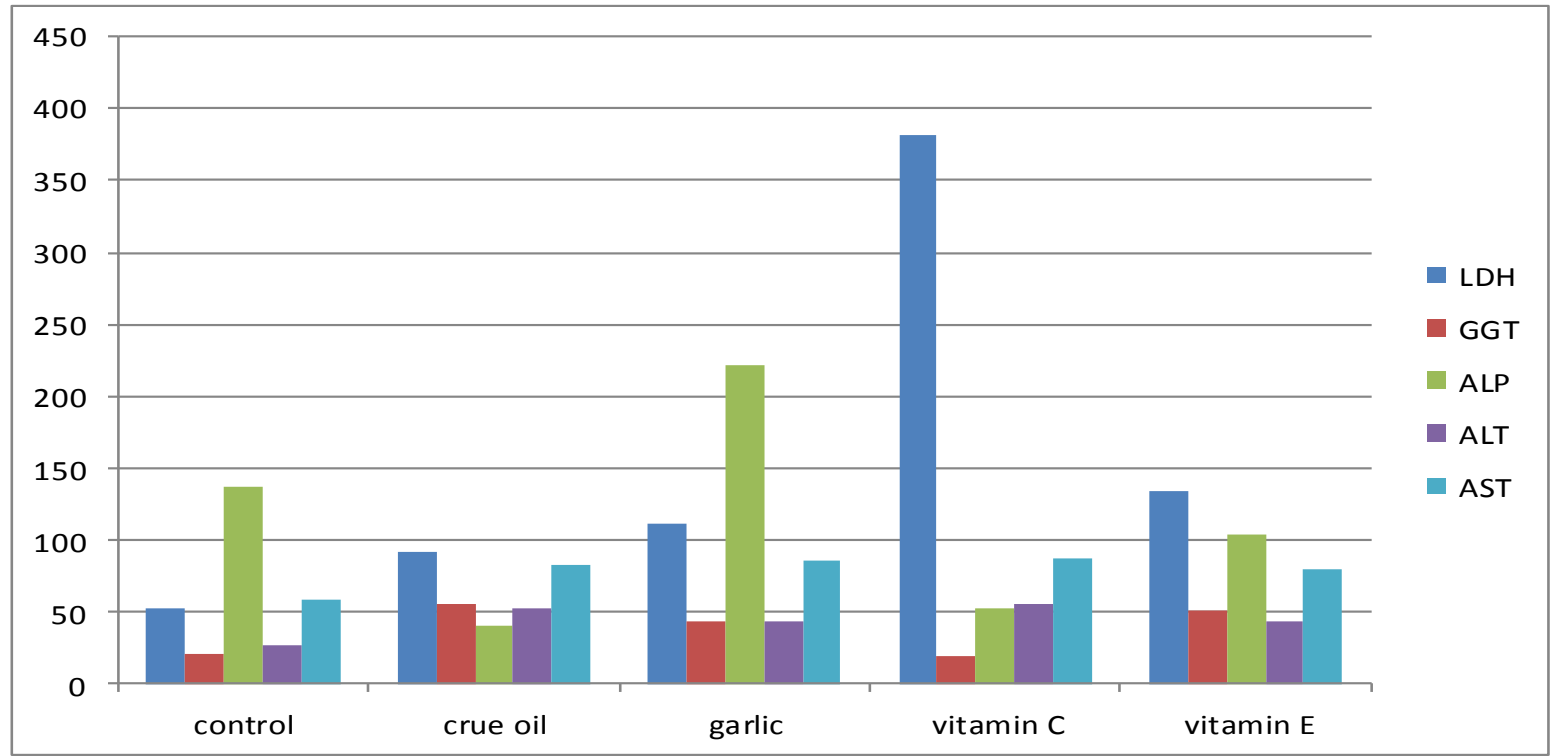

Values expressed in Mean \pm S.E.M of 8 determinations $\mathrm{a}=$ shows significant difference compared with positive control $(\mathrm{p}<0.05)$. $\mathrm{b}=$ shows significant difference compared with negative control $(\mathrm{p}<0.05)$

Fig.2 Effect crude oil contaminated feeds on serum enzymes level after 28 days of administration in Wistar rats

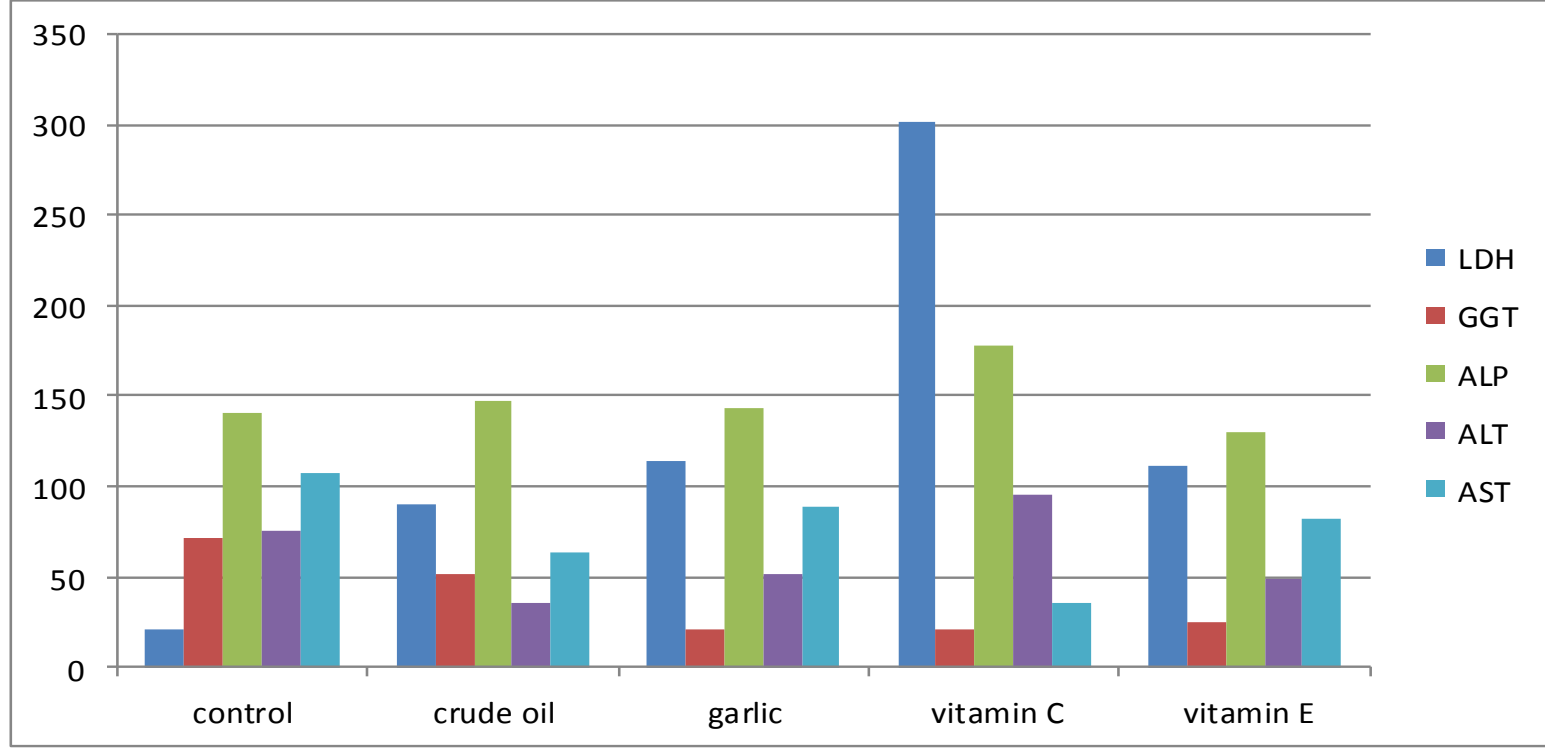

Values expressed in Mean \pm S.E.M of 8 determinations $a=$ shows significant difference compared with positive control $(\mathrm{p}<0.05)$. $\mathrm{b}=$ shows significant difference compared with negative control $(\mathrm{p}<0.05)$. 
Fig.3 Effect crude oil contaminated feeds on electrolyte and bilirubin level after 14 days of administration in Wistar rats

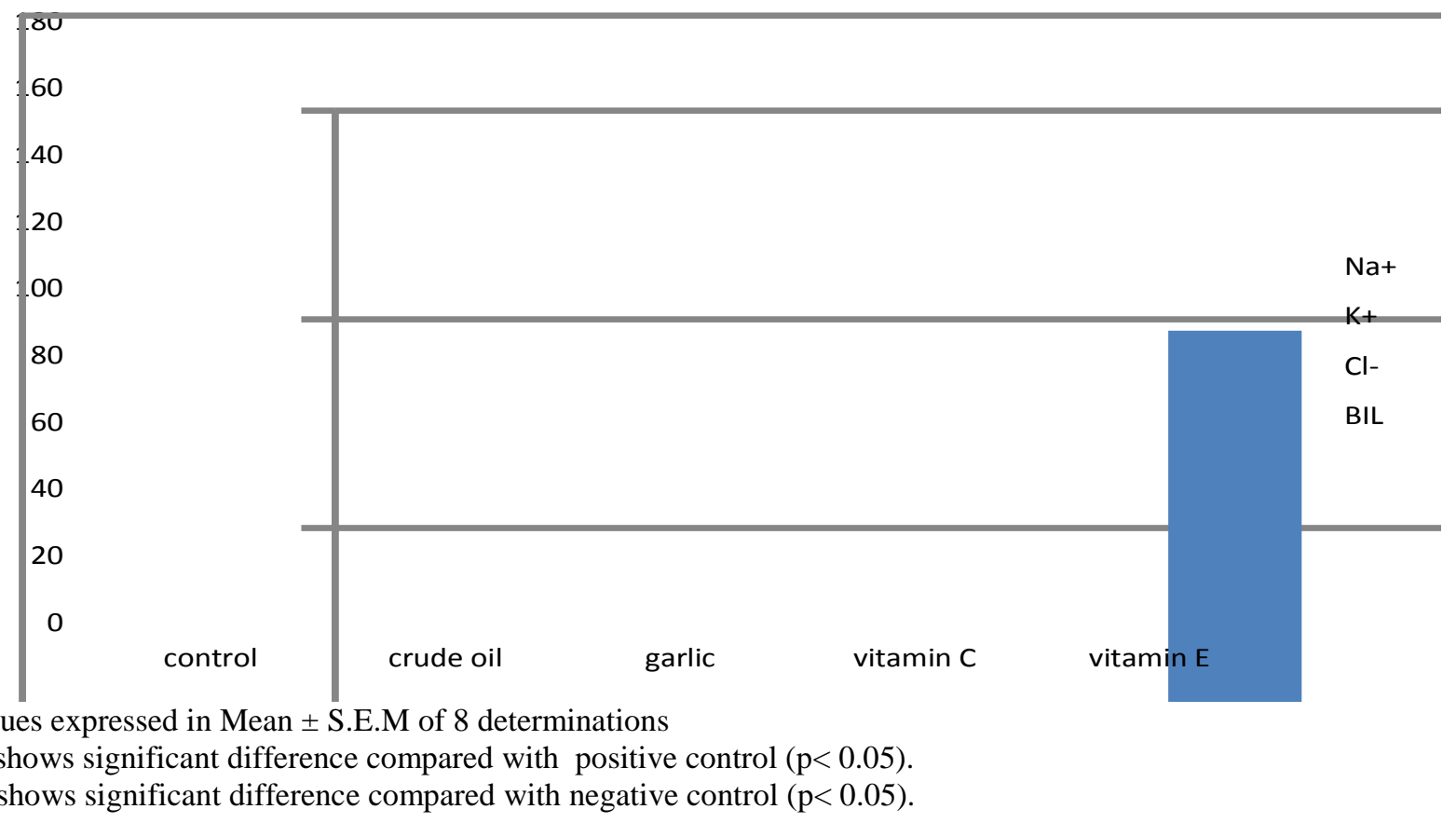

Fig.4 Effect crude oil contaminated feeds on electrolyte and bilirubin level after 28 days of administration in Wistar rats

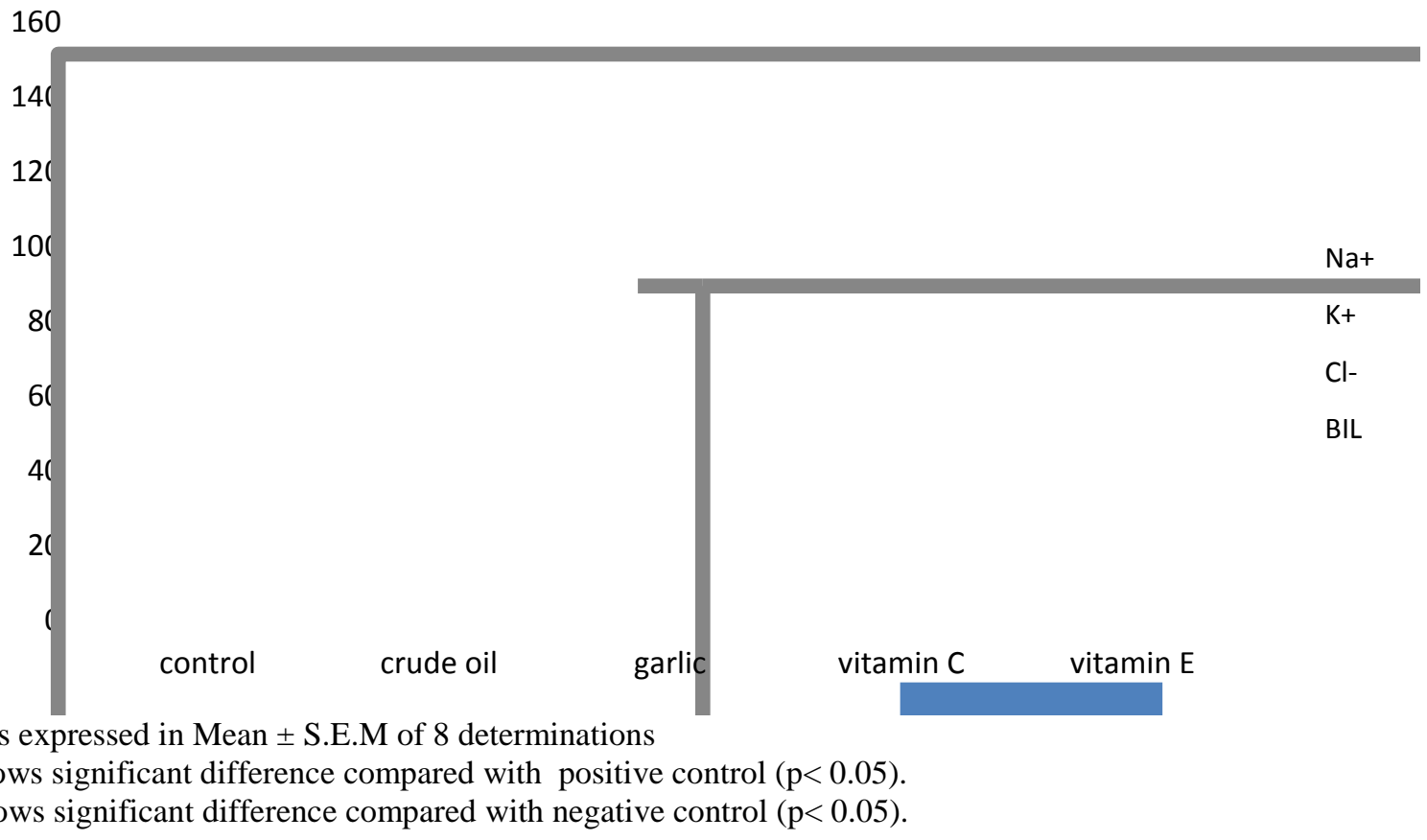


Chloride $\left(\mathrm{Cl}^{-}\right)$levels was significantly high $(\mathrm{P}>0.05)$ in vitamin $\mathrm{C}$ and vitamin $\mathrm{E}$ treated groups (101.0 \pm 0.03 and $97.9 \pm 0.03)$ while it is significantly low $(\mathrm{P}<0.05)$ in garlic treated group (92.9 \pm 0.06$)$. Bilirubin concentration was significantly high $(\mathrm{P}>0.05)$ in garlic, vitamin $\mathrm{C}$ and vitamin $\mathrm{E}$ treated groups $(6.9 \pm 0.05,7.9 \pm 0.04$ and $9.9 \pm 0.04)$.

This research explored the ameliorative effects of garlic, vitamin $\mathrm{C}$ and vitamin $\mathrm{E}$ on serum enzymes and electrolyte of crude oil contaminated feed. Exposure of humans and animals to crude oil contamination is at the alarming rate as a result of the environmental, land and water pollution which pose great threat to body physiological and homeostatic state. Several organs, mainly heart and liver, cell damage is followed by increased levels of a number of cytoplasm enzymes in the blood, a phenomenon that provides the basis for clinical diagnosis of heart and liver diseases. For example, liver enzymes such as alanine transaminase and aspartate transaminase are usually raised in acute hepatotoxicity but tend to decrease with prolonged intoxication due to damage to the liver cells. The electrolyte balance in the body is greatly affected as a result of the crude oil contaminated feed. There are many enzymes such as phosphatases, dehydrogenases and transferases that are found in the serum which did not originate from the extracellular fluid. During tissue damage, some of these biomolecules find their way into the serum, probably by leakage through disrupted cell membranes. The increase in serum alkaline phosphatase, glutamaic pyruvic transferase and glutamic oxaloacetic as the concentration of crude oil increased. The mechanisms by which these enzymes are present in high concentration in the blood has been attributed to one in which their membrane pockets are damaged thereby leading to abnormal amounts being released into the blood. This corroborates with the previous evidence found in (Corpas et al., 2001) reported that serum alkaline phosphatase levels obtained from blood of rats fed on crude oil contaminated diets were elevated. From table 1 which represent the comparism and the effects of the garlic, vitamin $\mathrm{C}$ and vitamin $\mathrm{E}$ drugs on serum enzymes; LDH, GGT, ALP, ALT and AST with positive control and negative control. The levels of LDH and GGT concentrations increased significantly ( $>0.05)$ with both positive control and crude oil control except in LDH which showed low concentration on treatment with vitamin $\mathrm{E}$ $(\mathrm{P}<0.05)$. Garlic and vitamin $\mathrm{C}$ therefore do not have effect on the increased LDH and GGT levels of crude oil contamination. Vitamin E therefore reduced the toxic effect of the crude oil contamination on LDH significantly after the 14 days. The observed significant $(\mathrm{P}>0.05)$ increased in the activities of AST, ALT, ALP in rats fed crude oil contaminated diet as compared to the control agreed with the results of previous studies on crude petroleum and refined petroleum products (Maldonado et al., 2006). The elevated levels of serum marker enzymes indicate cellular leakage due to damage of the structural integrity of the liver (Baranano et al., 2002). In this study, the levels of ALT and AST after 28 days increased significantly $(\mathrm{P}>0.05)$ and the effect of garlic, vitamin $\mathrm{C}$ and vitamin $\mathrm{E}$ were not significant. However, vitamin $\mathrm{C}$ reduces the concentration of ALT which shows that it has effect on reducing the toxicity of crude oil contaminated feed. ALP generally showed reduction in the concentration after 28days as a result of the effect of garlic, vitamin $\mathrm{C}$ and vitamin $\mathrm{E}$ drugs therapeutic effect on the crude oil contaminated feed. The levels of Sodium, Potassium, Chloride ion and bilirubin were significantly low $(\mathrm{P}<0.05)$ at the first week when treated with the garlic, vitamin $\mathrm{C}$ and vitamin $\mathrm{E}$ drugs which show reduction in the 
toxicity of the crude oil contaminated feed on the blood electrolyte. However, at 28 day there were increase in concentration of sodium, potassium, and chloride and bilirubin level. Therefore, garlic, vitamin $\mathrm{C}$ and vitamin $\mathrm{E}$ drugs do not have therapeutic effect on the electrolytes and this is findings is agreement with the study of (Sunmonu and Oloyede, 2006) Recent findings have shown that in cases of toxicity, free radicals are generated enormously within a short period of time which in turn disrupts normal functions physiological (Halliwell and Gutteridge, 1989).

On the basis of the findings from this work and correlation with other works, it is evident that hydrocarbons found in crude oil influence, the body electrolyte, serum enzymes, physiology, health, growth and reproduction of living organisms. The observed physiological findings are also pointers to the toxicity of crude oil. The possible mechanism of crude oil toxicity was found to be elaborated in enlargement of the liver, increases in the lipid peroxidation products and total plasma protein levels.

\section{Competing Interest}

The authors affirm that there is no conflict of interest in the publication of this article.

\section{Ethical Approval}

All authors hereby declare that research has been determined exempt from review by the University animal research or ethics review committee and that the principles of laboratory animals care were strictly observed.

\section{References}

Abdullah, T.H., Kandil, O., Elkadi, A. and Carter, J. (1988). Garlic revisited: therapeutic for the major diseases of our times. J. Natl Med Assoc. 80: 439-445.

Achuba, F.I. and Osakwe, S.A. (2003). Petroleum induced free radical toxicity in African catfish (Claria gariepinus). Fish Physiol. Biochem., 29: 97-103

Alam, J.B., Ahmed, A.A.M., Munna, G.M. and Ahmed, A.A.M. (2010). Environmental impact assessment of oil and gas sector: A case study of Magurchara gas field. J. Soil Sci. Environ. Manage. 1(5):86

Al-Turki, A.I. (2010). Assessment of effluent quality of tertiary wastewater treatment plant at buraidah city and its reuse in irrigation. J. Applied Sci., 10: 17231731.

Baranano, D. E., Rao, M., Ferris, C. D., Snyder, S. H. (2002). Biliverdin reductase: A major physiologic cytoprotectant. Proc. Natl. Acad. Sci. USA. 99, p. 16093-16098.

Carocho, M. and Ferreira, I.C.F.R. (2013). A review on antioxidants, prooxidants and related controversy: Natural and synthetic compounds, screening and analysis methodologies and future perspectives. Food Chem. Toxicol. 51: 15-25

Chukwu, L.O. and Lawal, O.S. (2010). Joint action response and haematological profile of Macrobrachium

Colbborn, T., Vom saal, F.S. and Soto A.M. (1993). Developmental effects of endocrine disrupting chemical in wildlife and humans. Environ. Health Perspect. 101: 378-384.

Corpas, F. J., Barroso, J.B. and del Río, L.A. (2001). "Peroxisomes as a source of reactive oxygen species and nitric oxide signal molecules in plant cells." Trends Plant Sci., 6 (4): 145-50.

Doyle, C.J, and Lim, R.P. (2002). The effect of 17B-estraddi on the gonopodia development and sexual activity of 
Gambusia Holbrook. Environ. Tox. Chem. 21 (912). 2724.

Halliwell, B. and Gutteridge, J.M.C. (1985).

The chemistry of oxygen radicals and other oxygen-derived species. In: Free Radicals in Biology and Medicine. New York: Oxford University Press, p. 2064.

Ita, S.O. and Udofia, U.A. (2011). Comparative study of some hematological parameters in rats following ingestion of crude oil (Nigeria Bonny Light), petrol, kerosene and diesel Asian Journal of Biological Sciences, 4(6): 498-505.

Kuhad, R.C and Gupta, R. (2009). Biological remediation of petroleum contaminants. Soil Biol. 17: 173 -187

Maldonado, A. G., Doucet, J.P., Petitjean, M. and Fan, B.T., (2006). Molecular Diversity. Molecular Similarity and Diversity in Chemo informatics: From Theory Appl. J. 10: 39.

Nelson - Smith, A. (1972). Oil Pollution and Marine Ecology. Paul Clack Scientific Brok Ltd. London. 420p.

Niger Delta Development Commission (2006). Niger Delta regional development master plan: Popular version. Niger Delta Development Commission, Port Harcourt, Nigeria. p. 61.

Oloyede O.B, Adeyemi, O., Sunmonu, T.O. and Bakare A.A. (2003). The effect of polluted Oba water on selected rat liver enzymes. NISEB J. 3: 91-97.
Patrick - Iwuanyanwu, K.C., Onyemaenu, C. C., Wegwu, M.O. and Ayalogu, E.O. (2011). Hepatotoxic and nephrotoxic effects of kerosene and petrol contaminated diets in Wistar Albino rats. Res. J. Environ. Toxicol. 5(1): 4957.

Roussel, J. and Boulet, R. (1995). "Composition of Crude Oils and Petroleum Products", J. Pet. Refin. 1: 115, 453-460.

Shrivastava, R. (2011). Bhopal gas disaster: Review on health effects of methyl isocyanate. Res. Jour. Environ. Sci. 5(2): 150-156.

Sunmonu, T.O. and Oloyede, O.B. (2006). Changes in liver enzyme activities in African catfish (Clarias gariepinus) exposed to crude oil. Asian Fisheries Sci. 19: 104-109.

Wang, S., Yan, Z., Guo, G., Lu, G., Wang, Q. and Li, F. (2010). Ecotoxicity assessment of aged petroleum sludge using a suite of effects - based end points in earthworm Eisenia fetida. Environ. Mon. Assess. 169(1-4):417428.

Wang, Z., Fingas, M and Li, K. (1994). "Fractionation of a Light Crude Oil and Identification and Quantification of Aliphatic, Aromatic, and Biomarker Compounds by GC-FID and GC-MS, part I". J. Chromatogr. Sci. 32(9): 361366.

\section{How to cite this article:}

Ukpanukpong, R.U., D.I. Basiru, O.O. Obadare and Omang, W.A. 2018. Assessment of Selected Hepatic Serum Enzymes in Contaminated Crude-Oil Feeds on Albino Wistar Rats. Int.J.Curr.Microbiol.App.Sci. 7(08): 280-290. doi: https://doi.org/10.20546/ijcmas.2018.708.033 